\title{
Front Matter: Volume 9219
}

, "Front Matter: Volume 9219," Proc. SPIE 9219, Infrared Remote Sensing and Instrumentation XXII, 921901 (6 October 2014); doi: 10.1117/12.2086503

SPIE Event: SPIE Optical Engineering + Applications, 2014, San Diego, California, SPIE. United States 


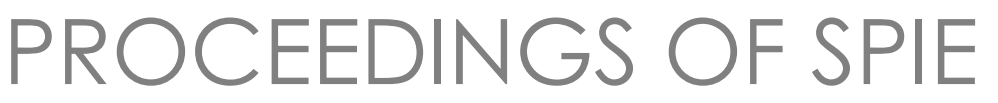

\title{
Infrared Remote Sensing and Instrumentation XXII
}

\author{
Marija Strojnik Scholl \\ Gonzalo Páez \\ Editors
}

18 August 2014

San Diego, California, United States

Sponsored and Published by

SPIE 
The papers included in this volume were part of the technical conference cited on the cover and title page. Papers were selected and subject to review by the editors and conference program committee. Some conference presentations may not be available for publication. The papers published in these proceedings reflect the work and thoughts of the authors and are published herein as submitted. The publisher is not responsible for the validity of the information or for any outcomes resulting from reliance thereon.

Please use the following format to cite material from this book:

Author(s), "Title of Paper," in Infrared Remote Sensing and Instrumentation XXII, edited by Marija Strojnik Scholl, Gonzalo Páez, Proceedings of SPIE Vol. 9219 (SPIE, Bellingham, WA, 2014) Article CID Number.

ISSN: 0277-786X

ISBN: 9781628412468

Published by

SPIE

P.O. Box 10, Bellingham, Washington 98227-0010 USA

Telephone +1 3606763290 (Pacific Time) · Fax +1 3606471445

SPIE.org

Copyright (@ 2014, Society of Photo-Optical Instrumentation Engineers.

Copying of material in this book for internal or personal use, or for the internal or personal use of specific clients, beyond the fair use provisions granted by the U.S. Copyright Law is authorized by SPIE subject to payment of copying fees. The Transactional Reporting Service base fee for this volume is $\$ 18.00$ per article (or portion thereof), which should be paid directly to the Copyright Clearance Center (CCC), 222 Rosewood Drive, Danvers, MA 01923. Payment may also be made electronically through CCC Online at copyright.com. Other copying for republication, resale, advertising or promotion, or any form of systematic or multiple reproduction of any material in this book is prohibited except with permission in writing from the publisher. The CCC fee code is 0277-786X/14/\$18.00.

Printed in the United States of America.

Publication of record for individual papers is online in the SPIE Digital Library.

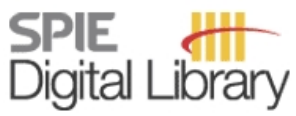

SPIEDigitalLibrary.org

Paper Numbering: Proceedings of SPIE follow an e-First publication model, with papers published first online and then in print and on CD-ROM. Papers are published as they are submitted and meet publication criteria. A unique, consistent, permanent citation identifier (CID) number is assigned to each article at the time of the first publication. Utilization of CIDs allows articles to be fully citable as soon as they are published online, and connects the same identifier to all online, print, and electronic versions of the publication. SPIE uses a six-digit CID article numbering system in which:

- The first four digits correspond to the SPIE volume number.

- The last two digits indicate publication order within the volume using a Base 36 numbering

system employing both numerals and letters. These two-number sets start with 00, 01, 02, 03, 04, $05,06,07,08,09,0 A, 0 B \ldots$. 0Z, followed by 10-1Z, 20-2Z, etc.

The CID Number appears on each page of the manuscript. The complete citation is used on the first page, and an abbreviated version on subsequent pages. Numbers in the index correspond to the last two digits of the six-digit CID Number. 


\title{
Contents
}

\author{
$\checkmark$ Authors \\ vii Conference Committee \\ ix Introduction
}

SESSION 1 INFRARED INSTRUMENTS I

921902 The GOSAT / TANSO interferometer after five years on orbit (Invited Paper) [9219-1]

921904 Onboard infrared signal processing system for asteroid sample return mission HAYABUSA2 [9219-3]

921906 Advancements in large-format SiPIN hybrid focal plane technology [9219-26]

\section{SESSION 2 INFRARED INSTRUMENTS II}

$921907 \mathrm{CO}_{2}$ phase and amplitude spectra measured over $2 \mathrm{~km}$ outdoor path with a dual-comb spectrometer [9219-5]

921908 AeroADL: applying the integration of the Suomi-NPP science algorithms with the Algorithm Development Library to the calibration and validation task [9219-7]

921909 Excellent approach to modeling urban expansion by fuzzy cellular automata: agent base model [9219-8]

\section{SESSION $3 \quad$ TECHNOLOGY FOR INFRARED INSTRUMENTS}

9219 OA Advanced simulation methods to detect resonant frequency stack up in focal plane design (Invited Paper) [9219-9]

9219 OB Cryogenic filter wheel design for an infrared instrument [9219-11]

9219 OC Preliminary study of the Suomi NPP VIIRS detector-level spectral response function effects for the long-wave infrared bands M15 and M16 [9219-12]

SESSION 4 REMOTE SENSING OF ACOUSTIC OR VIBRATION SIGNALS USING NON-TRADITIONAL DOMAINS

9219 OD Investigating potential correlations between jet engine noise and plume dynamics in the hypertemporal infrared domain [9219-13]

9219 OE Detecting small surface vibrations by passive electro-optical illumination [9219-14] 
9219 OF Feasibility considerations for a long-range passive vibrometer [9219-15]

921906 A passive optical technique to measure physical properties of a vibrating surface (Invited Paper) [9219-16]

POSTER SESSION

$9219 \mathrm{OH} \quad$ Spectroscopic measurement of ignition parameters in forest fuel [9219-17]

9219 Ol Supercontinuum spectrum in IR Bessel-Gauss and Gauss pulsed beam filament under anomalous group velocity dispersion in fused silica [9219-18]

9219 OJ Stand-off and up-close Raman detection of nitrates buried in sand and soils [9219-19]

9219 OL 3D shape measurement with binary phase-shifted technique and digital filters [9219-21]

9219 OM Gray coded trapezoidal fringes for 3D surface-shape measurement [9219-22]

9219 ON Evaluate the effective of annular aperture on the OTF for fractal optical modulator [9219-23]

921900 A near infrared-based downhole water-cut meter using neural network [9219-25]

9219 OP A monolithic deformable mirror with latchable mechanical actuation (LATCHAMAN) for space-borne telescopes [9219-32] 


\section{Authors}

Numbers in the index correspond to the last two digits of the six-digit citation identifier (CID) article numbering system used in Proceedings of SPIE. The first four digits reflect the volume number. Base 36 numbering is employed for the last two digits and indicates the order of articles within the volume. Numbers start with 00, 01, 02, 03, 04, 05, 06, 07, 08, 09, OA, OB...0Z, followed by 10-1Z, 20-2Z, etc.

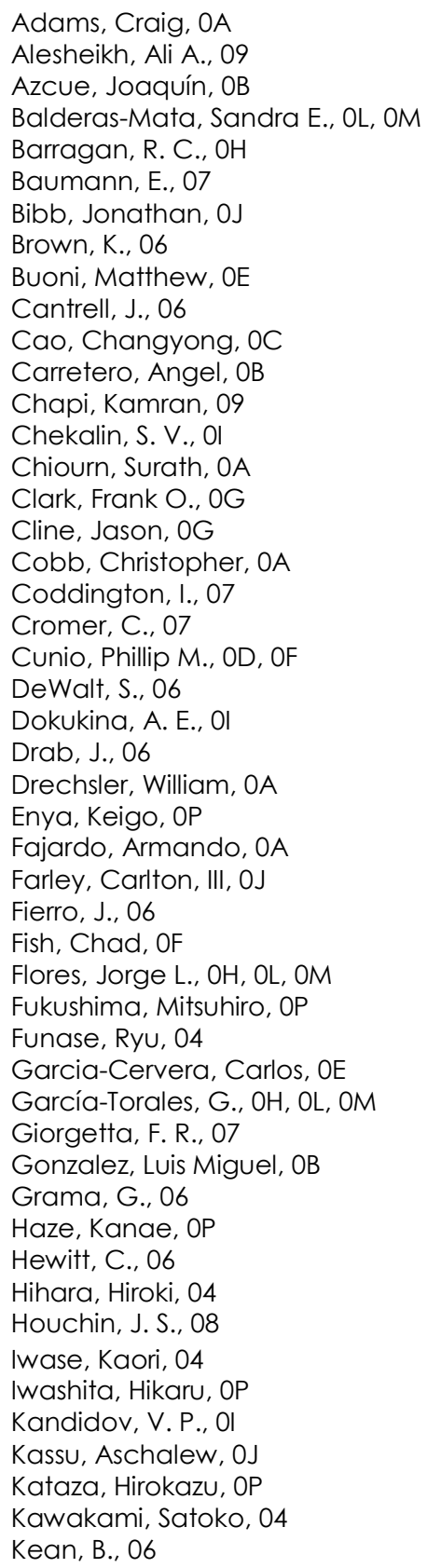

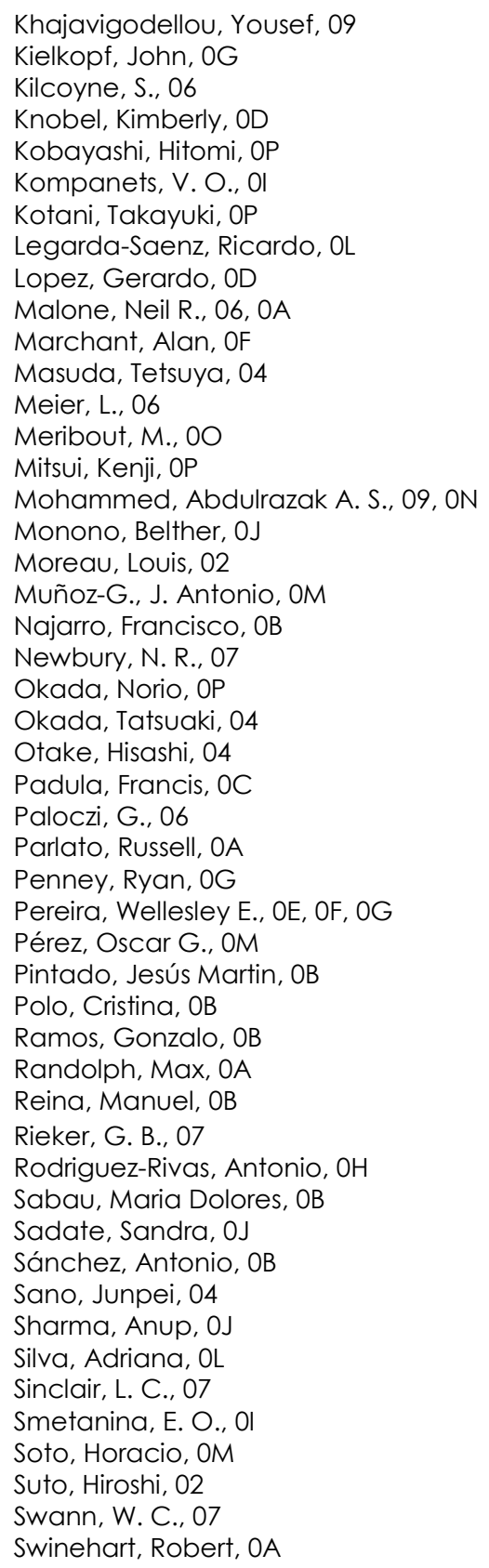


Takada, Jun, 04

Takahashi, Aoi, OP

Torres, Josefina, OB

Torres, Raymond, OA

Vampola, John, 06, 0A

Veilleux, James, 02

Villanueva, Carlos, OB

Wager, Jason, OD

Weber, Reed A., OD, OE

Witt, William, 0J

Wyles, J., 06

Yamamuro, Tomoyasu, OP

Yao, Jie, OF

Zolot, A. M., 07

Proc. of SPIE Vol. $9219921901-6$

Downloaded From: https://www.spiedigitallibrary.org/conference-proceedings-of-spie on 26 Apr 2023 Terms of Use: https://www.spiedigitallibrary.org/terms-of-use 


\section{Conference Committee}

Program Track Chair

Allen H.-L. Huang, University of Wisconsin-Madison (United States)

Conference Chairs

Marija Strojnik Scholl, Centro de Investigaciones en Óptica, A.C. (Mexico)

Gonzalo Páez, Centro de Investigaciones en Óptica, A.C. (Mexico)

Conference Program Committee

Gabriele E. Arnold, Deutsches Zentrum für Luft- und Raumfahrt e.V.

(Germany)

Gail J. Brown, Air Force Research Laboratory (United States)

Jam Farhoomand, TechnoScience Corporation (United States)

Gerald T. Fraser, National Institute of Standards and Technology (United States)

John C. Gille, University of Colorado at Boulder (United States)

Sarath D. Gunapala, Jet Propulsion Laboratory (United States)

Neil R. Malone, Raytheon Company (United States)

Stanley J. Wellard, Space Dynamics Laboratory (United States)

Jürgen Wolf, NASA Ames Research Center (United States)

Session Chairs

1 Infrared Instruments I

Marija Strojnik Scholl, Centro de Investigaciones en Óptica, A.C.

(Mexico)

Gonzalo Páez, Centro de Investigaciones en Óptica, A.C. (Mexico)

2 Infrared Instruments II

Gonzalo Páez, Centro de Investigaciones en Óptica, A.C. (Mexico)

Douglas R. Battles, HE Space Operations GmbH (Germany)

3 Technology for Infrared Instruments

Marija Strojnik Scholl, Centro de Investigaciones en Óptica, A.C. (Mexico)

4 Remote Sensing of Acoustic or Vibration Signals Using Non-traditional Domains

Wellesley Pereira, Air Force Research Laboratory (United States)

Frank O. Clark, Spectral Sciences, Inc. (United States) 
Proc. of SPIE Vol. $9219921901-8$

Downloaded From: https://www.spiedigitallibrary.org/conference-proceedings-of-spie on 26 Apr 2023 Terms of Use: https://www.spiedigitallibrary.org/terms-of-use 


\section{Introduction}

Once again, the conference on Infrared Remote Sensing and Instrumentation was held in San Diego, California, forming a part of the annual SPIE Optics + Photonics meeting, 16-21 August 2014. SPIE is a technical society dedicated to the advancement of science and engineering through the use of light. We completed the 22nd in the series of these conferences, being among the longest running conferences at the annual meeting. The next meeting will be held again in San Diego during August 2015.

On behalf of the readers of the proceedings, and especially on our own behalf, we wish to express our most profound appreciation to the authors-presenters and the lively audience who had more questions than we were able to accommodate during the sessions. The atmosphere at this conference proves that face-to-face discussions between the presenter and the curious listeners is needed for a true exchange of information, including, occasionally, a difference of opinion. Such lively discussion makes personal participation mandatory.

Nearly 25 papers were presented in this conference, with truly international scientific participation. A couple of presentations were cancelled with advanced warning, so alternate plans were put into action. The majority of presenters found the requisite time to write their research accomplishments up in a technical paper and submit their work for inclusion in the proceedings for future reference. Their work may also be downloaded from the SPIE Digital Library. The SPIE Digital Library continues to expand and offer more benefits to SPIE members, proceedings and journals authors, and readers.

Within the last few years, in the SPIE call-for-papers, there has been inserted a little advisory that all papers are reviewed by the chairs and members of the technical committee. Many SPIE participants used to make an assumption that this is just proforma, so our conferences would "look good". The truth is that each paper is read carefully by at least one chair, for as long as we have been involved in these activities. The conference organization attracts a person who is interested in many subjects, and who enjoys reading about new technology, engineering, and science. The papers at our conference have historically been of the highest levels, so the suggestions have to do mostly with formatting: maybe the European author forgot that the European paper size is different from that in the US, or the format changed automatically because computers know everything better. We believe that one more look at the final accomplished work makes the paper even better, and the conference proceedings book becomes even more useful as a reference.

Special thanks must be extended to the SPIE staff for providing friendly guidance and organizational support to meet all the deadlines. Organizing a technical conference and publishing Proceedings involves the hard work of a team of dedicated and knowledgeable people whose discrete advice to the chairs makes a conference a success. We thank them for their efficient assistance.

Marija Strojnik Gonzalo Páez 
Proc. of SPIE Vol. 9219 921901-10

Downloaded From: https://www.spiedigitallibrary.org/conference-proceedings-of-spie on 26 Apr 2023 Terms of Use: https://www.spiedigitallibrary.org/terms-of-use 